\title{
The prevalence of four virulence genes in strains of Campylobacter jejuni isolated from broilers in Serbia
}

\author{
Jelena Jovanović ${ }^{\text {, Ivana Branković-Lazić }{ }^{1} \text {, Tatjana Baltić1, Milica Jovanović }}$, \\ Vesna Đorđević ${ }^{1}$, Vlado Teodorović ${ }^{3}$, and Branko Velebit ${ }^{1 *}$ \\ ${ }^{1}$ Institute of Meat Hygiene and Technology, Belgrade, Serbia \\ ${ }^{2}$ Department of Microbiology, Clinical Centre of Serbia, Belgrade, Serbia \\ ${ }^{3}$ Faculty of Veterinary Medicine, University of Belgrade, Belgrade, Serbia
}

JOVANOVIĆ, J., I. BRANKOVIĆ-LAZIĆ, T. BALTIĆ, M. JOVANOVIĆ, V. ĐORĐEVIĆ, V. TEODOROVIĆ, B. VELEBIT: The prevalence of four virulence genes in strains of Campylobacter jejuni isolated from broilers in Serbia. Vet. arhiv 90, 39-45, 2020.

\section{ABSTRACT}

Campylobacter jejuni is a major cause of human diarrheal disease. The objective of this research study was to determine the prevalence of different virulence genes in isolates recovered from broiler meat at slaughterhouses in Serbia. Out of 115 Campylobacter spp. samples recovered, a total of 35 isolates were identified as C. jejuni on the basis of morphological, biochemical-based detection, multiplex PCR, and sequencing of the highly conserved region of the dnaJ gene encoding the DnaJ Hsp40 family protein. The isolates were screened for the presence of four pathogenic genes, namely $f a A, c a d F, c d t B$, and $c g t B$, which are responsible for the expression of adherence, colonization, cytotoxin production in $C$. jejuni, and the onset of Guillain-Barre syndrome. The isolates showed a wide variation in the presence of these genes. All the isolates were positive for $\mathrm{flaA}$. Furthermore, a high genetic heterogeneity in the $C$. jejuni population was found in this study, showing a pattern partially different from other reported virulence genes. Of the $C$. jejuni studied, $94.3 \%, 97.1 \%$ and $5.7 \%$ were positive for $c a d F, c d t B$ and $\operatorname{cgt} B$, respectively. This study provides initial data on the prevalence and distribution of the $f a A, c a d F, c d t B$, and $\operatorname{cgt} B$ genes in $C$. jejuni isolated from broiler meat in Serbia.

Key words: slaughterhouse; C. jejuni; virulence genes

\section{Introduction}

Thermophilic Campylobacter spp. is one of the most common causative agents of foodborne diseases in Europe (EFSA 2016). It is a zoonotic Gram-negative bacterial pathogen, frequently associated with acute gastroenteritis in both

industrialized and developing countries. In most cases, foodborne campylobacteriosis is caused by Campylobacter jejuni, however Campylobacter coli, and, to a lesser extent, Campylobacter lari have also been responsible for occurrence of

\footnotetext{
*Corresponding author:

Branko Velebit, PhD, DVM, Department of Microbiology and Molecular Biology, Institute of Meat Hygiene and Technology, Kaćanskog 13,11040 Belgrade, Serbia, Phone: +381 112650 655; Fax: +381 112651 825; E-mail: branko.velebit@inmes.rs
} 
infection. C. jejuni is particularly adapted to poultry, which undoubtedly constitutes the largest reservoir of the species. Contaminated water and foods of animal origin, especially improperly processed chicken, have been implicated as vehicles for the transmission of campylobacteriosis.

The clinical symptomatology of illness caused by C. jejuni includes diarrhoea, which may range from mild and watery to bloody dysentery. In addition to enteric disorders, C. jejuni infection is frequently associated with the development of immunoreactive complications, such as polyarthralgia, GuillainBarre and Miller-Fisher syndromes, and eventually death (DINGLE et al., 2002).

Unlike other enteric pathogens, such as Salmonella spp., Shiga-like toxigenic Escherichia coli and Noroviruses, the pathogenesis of $C$. jejuni is poorly understood. It is considered that motility, bacterial adhesion, invasion of the enterocytes and synthesis of toxin and hemolysin seem to be the main virulence factors. So far, it is known that this microorganism, upon initial colonization of the epithelial lining in the jejunum, moves towards the large intestines and eventually settles in the colon, which is the target organ (SILVA et al., 2011; HADDOCK et al., 2010). During primary interaction with enterocytes, $C$. jejuni adheres to them and then is internalized within the cells, causing tissue damage, inflammation and thus gastroenteritis. The factors associated in the invasion are capsular polysaccharide (CPS) and sialylation of the lipooligosaccharides outer core or Campylobacter invasive antigens (Cia) (WATSON and GALAN, 2008; LOUWEN et al., 2008). The binding of C. jejuni to fibronectin, a component of the extracellular matrix of eukaryotic cells, is mediated by a $37 \mathrm{kDa}$ outer membrane protein (adhesin), termed CadF, for Campylobacter adhesion to fibronectin. Previous studies have indicated that $C$. jejuni binds to fibronectin on the basolateral surface of human colonic cells (KONKEL et al., 2005). This factor is encoded by the $c a d F$ (Campylobacter Adhesion to Fibronectin F) gene (ZIPRIN et al., 2001).

C. jejuni possess a single polar flagellum at one or both ends of the cell. The flagellum consists of two proteins, FlaA and FlaB, with significantly more
FlaA incorporated into the flagellar filament (ALM et al., 1993). It is considered that the polar flagellum of $C$. jejuni is the primary adherence factor that establishes contact between the eukaryotic (both human and broiler) cell membrane and specific bacterial-invasion factors, hence facilitating the colonization of the intestinal epithelial cells (HU et al., 2008). The flagellar rotatory motion allows C. jejuni to move easily through the viscous mucus layer covering the intestinal epithelial cells, which consequently identifies the flagella as a virulence determinant. This virulence factor is encoded by the flaA gene (NUIJTEN et al., 2000).

Additional virulence factors, such as bacterial toxins synthesized by $C$. jejuni, play a role in the development of the disease, inducing enterocolitis. The most important ones include cytolethal distending toxin (CDT) and hemolysin. The $c d t A$, $c d t B$ and $c d t C$ genes have been identified for expression of cytotoxin production (PURDY et al., 2000). CDT production is important for interleukin-8 (IL-8) release by intestinal cells, which plays an important role in the host mucosal inflammatory response caused by C. jejuni (VAN DEUN et al., 2007). CDT is composed of three subunits: the catalytic subunit $\mathrm{CdtB}$, which is encoded by the $c d t B$ gene and has DNase I-like activity, whereas $\mathrm{CdtA}$, and $\mathrm{CdtC}$ are binding proteins for delivering $\mathrm{CdtB}$ into target cells. Translocation of CdtB to the nucleus induces genotoxic effects on the host DNA, triggering DNA repair cascades that lead to cell cycle arrest and eventual cell death.

Guillain-Barré syndrome (GBS) is an acute, immune-mediated, post infectionem illness affecting the peripheral nervous system, and is strongly associated with $C$. jejuni gastrointestinal infection (HUGHES and REES, 1997). Expression of ganglioside-like mimicry in the outer core lipooligosaccharide, and onset of an immune response in the host that cross-reacts with ganglioside-rich targets in the peripheral nerve, are considered to be involved in the pathogenesis of Campylobacter-induced GBS (MORAN and PRENDERGAST, 2001). The genes involved in the biosynthesis of ganglioside-mimicking lipooligosaccharide encompass were identified as cgtB and wlaN (LINTON et al., 2002). 
Aim of this study was to estimate the prevalence of $f l a A, c a d F, c d t B$ and $c g t B$ genes associated with virulence in $C$. jejuni isolated from broiler meat originating from different slaughterhouses in Serbia.

\section{Materials and methods}

Broiler meat samples. The autonomous province of Vojvodina, and the Western Serbia region were selected as the areas for collection of samples since $69 \%$ of the total Serbian broiler production is located in these regions and the surrounding area (RODIĆ et al., 2016). Six large and/or mid-scale slaughterhouses are located in this area. All of them were contacted and asked to collaborate in the study. On the basis of the outcome of this request, sampling was performed in 3 slaughterhouses. Between April and January, a total of 115 broiler meat samples were sampled. Meat samples included parts of carcasses, such as drumsticks $(n=84)$ and breast fillets $(\mathrm{n}=31)$. All batches sampled from the same slaughterhouse originated from different farms or broilers reared at different periods in the same farm. The broilers were commercially reared and slaughtered at the age of 6 to 7 weeks.

Isolation and identification of Campylobacter. The detection of Campylobacter isolates was performed according to the ISO 10272-1:2017 standard, respectively, using microaerophilic conditions generated by the GasPak gas-generating kit (BD, USA). The bacterial isolates were confirmed as $C$. jejuni using their morphological and biochemical features (a positive hippurate hydrolysis test), as well as a multiplex PCR method (a method developed in-house) and Sanger sequencing (described previously by VAN HUNG et al., 2011) of a fragment of the highly conserved dnaJ gene encoding DnaJ protein (a member of the Hsp40 family) which co-regulates the active form of heat shock sigma factor 32 . Nucleotide sequences of the dnaJ gene of the tested strains were deposited in Genbank under accession numbers KJ081720KJ081742. The strains were cryopreserved and stored at $-196{ }^{\circ} \mathrm{C}$ until further analysis.

Virulence genes characterization. Cryopreserved bacterial culture was reactivated by streaking on modified charcoal cefoperazone deoxycholate agar (mCCDA) supplemented with CCDA supplement
(Oxoid, USA), and incubated for 48 hours under microaerophilic conditions at $42{ }^{\circ} \mathrm{C}$. A loopful of cultivated colonies of each respective strain was resuspended in $200 \mu \mathrm{L}$ of Prepman Ultra Sample Preparation Reagent (Thermofisher, USA), and vortexed for 10-30 seconds. Samples were placed in a heat block (Eppendorf, Germany) set to 95 ${ }^{\circ} \mathrm{C}$, for 10 minutes. After cooling, samples were centrifuged in a microcentrifuge (Eppendorf, Germany) at $13.000 \times g$ for 2 minutes. Nanodrop 1000 (Thermo Scientific, USA) was used to assess the extracted DNA purity, measured as the ratio of absorbance at 260 and $280 \mathrm{~nm}$ (A260/280). A 50 $\mu \mathrm{L}$ of the recovered supernatant was used as stock DNA for subsequent PCR reactions, for detection of virulence genes. The reference strain $C$. jejuni ATCC33560 was used as a positive control.

A PCR technique was also used to target the $f l a A, c a d F, c d t B$, and $c g t B$ genes, respectively. The primer sequences of all the genes, the size of PCR amplicons and the PCR annealing temperature used in this study are shown in Table 1.

All PCR amplifications were performed in a reaction mixture of $50 \mu \mathrm{L}$ containing $1 \times$ AmpliTaq Gold 360 Master Mix (Thermofisher, USA), $0.4 \mu \mathrm{M}$ of each primer (Microsynth, Switzerland), and $5 \mu \mathrm{L}$ of the extracted template DNA. Nuclease free water was added to make up the final volume to $50 \mu \mathrm{L}$. The reaction mix was subjected to amplification in a PCR thermal cycler (Applied Biosystems, USA). The amplification program for these virulence markers involved initial denaturation at $95{ }^{\circ} \mathrm{C}$ for 5 minutes and the cyclic phase was repeated 35 times. Each cycle involved denaturation at $95{ }^{\circ} \mathrm{C}$ for 60 $\mathrm{s}$, annealing for $60 \mathrm{~s}$, and elongation at $72{ }^{\circ} \mathrm{C}$ for $60 \mathrm{~s}$, with final extension at $72{ }^{\circ} \mathrm{C}$ for 10 minutes. The corresponding annealing temperature is shown in Table 1.

Appropriate negative controls, with the PCR master mix, without the DNA template, were included with each PCR run. PCR amplification products were visualized on $1.5 \%$ agarose gel (Thermofisher, USA) in Tris-Acetated-EDTA buffer at $100 \mathrm{~V}$. The gel was stained using $1 \times$ SYBR Safe DNA Gel Stain (Invitrogen, USA) and 100 bp ladder (Bioline, UK) was used as a molecularweight size marker. 
Table 1. Nucleotide sequences of the primers used, annealing temperatures and the size of the amplicons

\begin{tabular}{|c|c|c|c|c|c|}
\hline $\begin{array}{l}\text { Primer } \\
\text { name }\end{array}$ & Sequence & $\begin{array}{l}\text { Annealing } \\
\text { temperature }\end{array}$ & $\begin{array}{c}\text { Amplicon } \\
\text { size (bp) }\end{array}$ & Specificity & Reference \\
\hline flaA-f & ATGGGATTTCGTATTAACAC & \multirow{2}{*}{$52{ }^{\circ} \mathrm{C}$} & \multirow{2}{*}{1713} & \multirow{2}{*}{ flaA } & \multirow{2}{*}{ Hanel et al., 2004} \\
\hline flaA-r & CTGTAGTAATCTTAAAACATTTTG & & & & \\
\hline cadF-f & TTGAAGGTAATTTAGATATG & \multirow{2}{*}{$48{ }^{\circ} \mathrm{C}$} & \multirow{2}{*}{400} & \multirow{2}{*}{$c a d F$} & \multirow{2}{*}{$\begin{array}{l}\text { Konkel et al., } \\
1999\end{array}$} \\
\hline cadF-r & CTAATCCTAAAGTTGAAAC & & & & \\
\hline cdtB-f & GTTAAAATCCCCTGCTATCAACCA & \multirow{2}{*}{$55^{\circ} \mathrm{C}$} & \multirow{2}{*}{495} & \multirow{2}{*}{$c d t B$} & \multirow{2}{*}{$\begin{array}{l}\text { Pickett et al., } \\
1996\end{array}$} \\
\hline cdtB-r & GTTGGCACTTGGAATTTGCAAGGC & & & & \\
\hline cgtB-f & TAAGAGCAAGATATGAAGGTG & \multirow{2}{*}{$52{ }^{\circ} \mathrm{C}$} & \multirow{2}{*}{561} & \multirow{2}{*}{$\operatorname{cgt} B$} & \multirow{2}{*}{ Linton et al, 2002} \\
\hline cgtB-r & GCACATAGAGAACGCTACAA & & & & \\
\hline
\end{tabular}

\section{Results}

Distribution of virulence genes. In total, 115 broiler meat samples were examined for the presence of Campylobacter spp. It was found that 89 samples $(77.4 \%)$ of the broiler carcasses' parts were contaminated with Campylobacter spp. Both phenotypical and PCR identification revealed that C. jejuni was isolated in 35 samples $(39.3 \%)$, whereas $C$. coli was detected in the remaining 54 samples $(60.7 \%)$. All 35 strains of $C$. jejuni were screened for the presence of the aforementioned four virulence genes. The prevalence of the flaA gene was $100 \%(35 / 35)$, while the cadF gene was detected in 33 isolates $(94.3 \%)$. Next, the $c d t B$ gene was found in $97.1 \%(34 / 35)$ of strains. Finally, the prevalence of the $\operatorname{cgt} B$ gene was just $5.7 \%(2 / 35)$. The gene prevalence pattern discloses that all strains contained one (flaA) virulence gene, while the majority (>94\%) of them, besides flaA, contained two more virulence markers ( $c a d F$ and $c d t B$ ). A complete set of four virulence genes was found in just 3 strains.

\section{Discussion}

According to EFSA (2017), the occurrence of Campylobacter remains high in broiler meat, mostly due to inadequate heat treatment and improper handling. Identification of virulence markers is becoming essential for consumer safety.

In this study, the prevalence of the four genes most frequently involved in the pathogenesis of campylobacteriosis was analysed in a group of $C$. jejuni isolated from broiler carcass parts during the spring-winter period in Serbian slaughterhouses.

The results of our research showed that the flaA gene was present in all $C$. jejuni strains tested. Previous studies showed that the detection rate of the flaA gene was between 95\% (THAKUR et al., 2010; EL-JAKEE et al., 2015) and 100\% (WIECZOREK et al., 2012; CASABONNE et al., 2016). Given its high prevalence, it is clear that the flaA gene plays a critical role in the bacterial colonization of the ileum and colon, by mean of encoding proteins of the flagellar filament necessary to move against peristaltic movements, penetration of the epithelial mucus, and colonization of enterocytes.

In the group of Serbian $C$. jejuni strains, the prevalence of $c a d F$ gene was $94.3 \%$ i.e. this gene was detected in all but 2 strains. In a study by ABU-MADI et al. (2016), they reported s similar prevalence $(96.6 \%)$, however other researchers have reported that the prevalence of this gene in strains isolated from poultry carcasses, faeces, and from human clinical specimens was 100\% (ROZYNEK et al., 2005; TALUKDER et al., 2008; SZCZEPAŃSKA et al., 2015; CASABONNE et al., 2016). The failure to detect the $c a d F$ gene in 2 strains may be explained by possible mutation(s) in the oligonucleotide sequence meaning that primers are unlikely to anneal the DNA template. It is certain that the $c a d F$ gene is highly conservative 
among the $C$. jejuni species, and the CadF protein was responsible for the initiation of interaction between bacterial cells and host epithelium surface receptors (KONKEL et al., 2005).

In this study, the prevalence of the CDT toxinencoding gene was investigated. CDT toxin consists of three subunits: CdtA, CdtB, and CdtC. All three proteins are required jointly in order to induce the cytotoxic effect. However, it is considered that only the CdtB subunit has enzymatic activity, and mediates DNA degradation and cell cycle blocking (PURDY et al., 2000). PCR testing of the $C$. jejuni strains in our study revealed that almost all of them harboured the $c d t B$ gene. (34/35). This was in accordance with reports published by THAKUR et al. (2010); GONZALEZ-HEIN et al. (2014); SZCZEPAŃSKA et al. (2015); CASABONNE et al. (2016). Although it is generally accepted that the $c d t B$ genes are widespread amongst poultry, cattle and human isolates in different countries (VAN DEUN et al., 2007), there have been some contradictory results when it comes to the prevalence of $c d t B$ in Asia. Namely, RIZAL et al., 2010 reported an unusual low prevalence of $c d t \mathrm{~A}$, $c d t B$ and $c d t C$ genes in chicken meat $(13.33 \%$, $20 \%, 35 \%$, respectively) in India. The same authors speculated that the results occurred due to genetic reasons or variations in the isolates from different geographic areas. However, TALUKDER et al. (2008) reported that in Bangladesh the prevalence of $c d t A$ was $97.5 \%, c d t B 97.5 \%$ ) and $c d t C 97.5 \%$.

Finally, the prevalence of the $c g t B$ gene in $C$. jejuni strains from Serbia was quite low $-5.7 \%$. This gene is closely associated with the onset of GuillainBarre syndrome since it encodes lipooligosaccharide that cross-reacts with ganglioside-rich targets in the peripheral nerve. Data on the frequency of $c g t B$ are scarce; so far KORDINAS et al. (2005) has reported that the prevalence in human $C$. jejuni strains was $24.4 \%$, NGUYEN et al. (2016) found prevalence of $55.6 \%$, while CASABONNE et al. (2016) detected the $\operatorname{cgt} B$ gene in just $6.7 \%$ of strains.

\section{Conclusion}

In summary, the high prevalence of the three genes in C. jejuni associated with motility, intestinal colonization and toxin synthesis confirmed that these pathogenic markers are widespread among the isolates from broiler meat in Serbian slaughterhouses. Furthermore, in this study, a high genetic heterogeneity was found in the $C$. jejuni population, showing a pattern partially different from other reported virulence genes. Combining the prevalence of this genes with the fact that the infective dose is low $(500 \mathrm{cfu} / \mathrm{g})$ indicates that the consumption of undercooked broiler meat may pose a serious threat to veterinary public health and consumers.

\section{Acknowledgments}

This paper was supported by the Serbian Ministry of Education, Science and Technological Development, Grant No. III 46009.

\section{References}

ABU-MADI, M., J. M. BEHNKE,A.SHARMA, R. BEARDEN, N. AL-BANNA (2016): Prevalence of virulence/stress genes in Campylobacter jejuni from chicken meat sold in Qatari retail outlets. PLoS One. 11:e0156938.

DOI: 10.1371/journal.pone.0156938

ALM, R. A., P. GUERRY, T. J. TRUST (1993): The Campylobacter sigma 54 flaB flagellin promoter is subject to environmental regulation. J. Bacteriol. 175, 4448-4455.

DOI: $10.1128 /$ jb.175.14.4448-4455.1993

CASABONNE, C., A. GONZALEZ, V. AQUILI, T. SUBILS, C. BALAGUE (2016): Prevalence of seven virulence genes of Campylobacter jejuni isolated from patients with diarrhea in Rosario, Argentina. Int. J. Infect, 3:e37727

DOI: $10.17795 / \mathrm{iji}-37727$

DINGLE, K. E., N. VAN DEN BRAAK, F. M. COLLES, L. J. PRICE, D. L. WOODWARD, F. G. RODGERS, H. P. ENDTZ, A. VAN BELKUM, M. C. J. MAIDEN (2002): Sequence typing confirms that Campylobacter jejuni strains associated with Guillain-Barre and Miller-Fisher syndromes are of diverse genetic lineage, serotype, and flagella type. J. Peripher. Nerv. 7, 68-68.

DOI: 10.1046/j.1529-8027.2002.2008_16.x

EFSA, The European Union summary report on trends and sources of zoonoses, zoonotic agents and food-borne outbreaks in 2016. EFSA Journal 2017; 15, 5077,

DOI: $10.2903 /$ j.efsa.2017.5077

EL-JAKEE, J., N. S. ATA, A. S. HAKIM, S. M. SYAME, S. T. OMARA (2015): Prevalence of virulence genes and antimicrobial resistance patterns of Campylobacter species isolated from chicken in Egypt. Asian J. Poult. Sci., 9, 250261.

DOI:10.3923/ajpsaj.2015.250.261

GONZÁLEZ-HEIN, G., B. HUARACÁN, P. GARCÍA, G. FIGUEROA (2014): Prevalence of virulence genes in 
strains of Campylobacter jejuni isolated from human, bovine and broiler. Braz. J. Microbiol. 44, 1223-1229.

DOI: $10.1590 / \mathrm{s} 1517-83822013000400028$

HADDOCK, G., M. MULLIN, A. MACCALLUM, A. SHERRY, L. TETLEY, E. WATSON, M. DAGLEISH, D. G. E. SMITH, P. EVEREST (2010): Campylobacter jejuni 81-176 forms distinct microcolonies on in vitro-infected human small intestinal tissue prior to biofilm formation. Microbiology. 156, 3079-3084.

DOI: $10.1099 / \mathrm{mic} .0 .039867-0$

HÄNEL, I., J. MÜLLER, W. MÜLLER, F. SCHULZE (2004): Correlation between invasion of Caco-2 eukaryotic cells and colonization ability in the chick gut in Campylobacter jejuni. Vet. Microbiol. 101, 75-82.

DOI: 10.1016/j.vetmic.2004.04.004

HU, L., B. D. TALL, S. K. CURTIS, D. J. KOPECKO (2008): Enhanced microscopic definition of Campylobacter jejuni 81-176 adherence to, invasion of, translocation across, and exocytosis from polarized human intestinal Caco-2 cells. Infect. Immun. 76, 5294-5304.

DOI: 10.1128/iai.01408-07

HUGHES, R. A. C., J. H. REES (1997): Clinical and epidemiologic features of Guillain-Barré Syndrome. J. Infect. Dis. 176(s2), S92-S98.

DOI: $10.1086 / 513793$

KONKEL, M. E., J. E. CHRISTENSEN, A. M. KEECH, M. R. MONTEVILLE, J. D. KLENA, S. G. GARVIS (2005): Identification of a fibronectin-binding domain within the Campylobacter jejuni CadF protein. Mol. Microbiol. 57, 1022-1035.

DOI: $10.1111 / j .1365-2958.2005 .04744 . x$

KONKEL, M. E., S. A. GRAY, B. J. KIM, S. G. GARVIS, J. YOON (1999): Identification of the enteropathogens Campylobacter jejuni and Campylobacter coli based on the $c a d F$ virulence gene and its product. J. Clin. Microbiol. 37, 510-517

DOI: 10.1128/JCM.37.3.510-517.1999

KORDINAS, V., C. NICOLAOU, A. IOANNIDIS, E. PAPAVASILEIOU, N. LEGAKIS, S. CHATZIPANAGIOTOU (2005). Prevalence of four virulence genes in Campylobacter jejuni determined by PCR and sequence analysis. Mol. Diagn. 9, 211-215.

DOI: 10.2165/00066982-200509040-00008

LINTON, D., M. GILBERT, P. G. HITCHEN, A. DELL, H. R. MORRIS, W. W. WAKARCHUK, N. A. GREGSON, B. W. WREN (2002): Phase variation of a $\beta-1,3$ galactosyltransferase involved in generation of the ganglioside GM1-like lipo-oligosaccharide of Campylobacter jejuni. Mol. Microbiol. 37, 501-514.

DOI: $10.1046 /$ j.1365-2958.2000.02020.x

LOUWEN, R., A. HEIKEMA, A. VAN BELKUM, A. OTT, M. GILBERT, W. ANG, H. P. ENDTZ, M. P. Bergam, E. E. NIEUWENHUIS (2008): The sialylated lipooligosaccharide outer core in Campylobacter jejuni is an important determinant for epithelial cell invasion. Infect. Immun. 76, 4431-4438.

DOI: $10.1128 /$ iai.00321-08

MORAN, A., M. PRENDERGAST (2001): Molecular mimicry in Campylobacter jejuni and Helicobacter pylori lipopolysaccharides: contribution of gastrointestinal infections to autoimmunity. J. Autoimmun, 16, 241-256.

DOI: $10.1006 /$ jaut.2000.0490

NGUYEN, T. N. M., H. HOTZEL, H. EL-ADAWY, H. T. TRAN, M. T. H. LE, H. TOMASO, H. NEUBAUER, H. M. HAFEZ (2016): Genotyping and antibiotic resistance of thermophilic Campylobacter isolated from chicken and pig meat in Vietnam. Gut Pathog. 8.

DOI: $10.1186 / \mathrm{s} 13099-016-0100-\mathrm{x}$

NUIJTEN, P. J. M.,A. J. G. VAN DEN BERG, I. FORMENTINI, B. A. M. VAN DER ZEIJST, A. A. C. JACOBS (2000): DNA rearrangements in the flagellin locus of an $f l a A$ mutant of Campylobacter jejuni during colonization of chicken ceca. Infect. Immun. 68, 7137-7140.

DOI: 10.1128/iai.68.12.7137-7140.2000

PICKETT, C. L., E. C. PESCI, D. L. COTTLE, G. RUSSELL, A. N. H. ERDEMZEYTIN (1996): Prevalence of cytolethal distending toxin production in Campylobacter jejuni and relatedness of Campylobacter sp. $c d t B$ gene. Infect. Immun. 64, 2070-2078.

PURDY, D., S. A. LEACH, A. E. HODGSON, C. M. BUSWELL, I. HENDERSON, K. McALPINE (2000): Characterisation of cytolethal distending toxin (CDT) mutants of Campylobacter jejuni. J. Med. Microbiol. 49, 473-479.

DOI: $10.1099 / 0022-1317-49-5-473$

RIZAL, A., A. KUMAR, A. S. VIDYARTHI (2010): Prevalence of pathogenic genes in Campylobacter jejuni isolated from poultry and human. Internet J. Food Safety 12, 29-34.

RODIĆ, V., L. PERIĆ, N. VUKELIĆ (2016): Regional distribution of poultry production in Serbia. Agroekonomika, 45-72, 1-9.

ROZYNEK, E., K. DZIERZANOWSKA-FANGRAT, P. JOZWIAK, J. POPOWSKI, D. KORSAK, D. DZIERZANOWSKA (2005): Prevalence of potential virulence markers in Polish Campylobacter jejuni and Campylobacter coli isolates obtained from hospitalized children and from chicken carcasses. J. Med. Microbiol. 54, pp. 615-619.

DOI: $10.1099 / j m m .0 .45988-0$

SILVA, J., D. LEITE, M. FERNANDES, C. MENA, P. A. GIBBS, P. TEIXEIRA (2011): Campylobacter spp. as a foodborne pathogen: A review. Front. Microbiol. 2. DOI: $10.3389 /$ fmicb.2011.00200

SZCZEPAŃSKA, B., P. KAMIŃSKI, M. ANDRZEJEWSKA, D. ŚPICA, E. KARTANAS, W. ULRICH, L. JERZAK, M. KASPRZAK, M. BOCHEŃSKI, J. J. KLAWE (2015): 
Prevalence, virulence, and antimicrobial resistance of Campylobacter jejuni and Campylobacter coli in white stork Ciconia ciconia in Poland. Foodborne Pathog. Dis. 12, 24-31.

DOI: $10.1089 /$ fpd.2014.1793

TALUKDER, K. A., M. ASLAM, Z. ISLAM, I. J. AZMI, D. K. DUTTA, S. HOSSAIN, A. NUR-E-KAMAL, G. B. NAIR, A. CRAVIOTO, D. A. SACK, H. P. ENDTZ (2008): Prevalence of virulence genes and cytolethal distending toxin production in Campylobacter jejuni isolates from diarrheal patients in Bangladesh. J. Clin. Microbiol. 46, 1485-1488.

DOI: $10.1128 / \mathrm{jcm} .01912-07$

THAKUR, S., S. ZHAO, P. F. MCDERMOTT, H. HARBOTTLE, J. ABBOTT, L. ENGLISH, W. A. GEBREYES, D. G. WHITE (2010): Antimicrobial resistance, virulence, and genotypic profile comparison of Campylobacter jejuni and Campylobacter coli isolated from humans and retail meats. Foodborne Pathog. Dis. 7, 835-844.

DOI: $10.1089 /$ fpd.2009.0487

VAN DEUN, K., F. HAESEBROUCK, M. HEYNDRICKX, H. FAVOREEL, J. DEWULF, L. CEELEN, L. DUMEZ, W. MESSENS, S. LELEU, F. VAN IMMERSEEL, R. DUCATELLE (2007): Virulence properties of Campylobacter jejuni isolates of poultry and human origin. J. Med. Microbiol. 56, 1284-1289.

DOI: $10.1099 / j m m .0 .47342-0$
VAN HUNG, P., J. ZHANG, M. HAYASHI, S. YOSHIDA, K. OHKUSU, T. EZAKI (2011): Genetic relatedness and identification of clinical strains of genus Campylobacter based on dnaJ, 16S rRNA, groEL, and rpoB gene sequences. Microbiol. Cult. Coll. 27, 1-12.

WATSON, R. O., J. E. GALÁN (2008): Campylobacter jejuni survives within epithelial cells by avoiding delivery to lysosomes. PLoS Pathog 4, e14.

DOI: 10.1371/journal.ppat.0040014

WIECZOREK, K., R. SZEWCZYK, J. OSEK (2012): Prevalence, antimicrobial resistance, and molecular characterization of Campylobacter jejuni and C. coli isolated from retail raw meat in Poland. Vet. Med. (Praha) 57, 293-299.

DOI: $10.17221 / 6016$-vetmed

ZIPRIN, R. L., C. R. YOUNG, J. A BYRD, L. H. STANKER, M. E. HUME, S. A. GRAY, M. E. KONKEL (2001): Role of Campylobacter jejuni potential virulence genes in cecal colonization. Avian Dis. 45, 549-557.

DOI: $10.2307 / 1592894$

Received: 11 September 2018

Accepted: 26 March 2019

JOVANOVIĆ, J., I. BRANKOVIĆ-LAZIĆ, T. BALTIĆ, M. JOVANOVIĆ, V. ĐORĐEVIĆ, V. TEODOROVIĆ, B. VELEBIT: Prevalencija četiri gena virulentnosti u sojevima Campylobacter jejuni izoliranima iz mesa brojlera u Srbiji. Vet. arhiv 90, 39-45, 2020.

\section{SAŽETAK}

Campylobacter jejuni vodeći je uzročnik crijevnih bolesti koje se očituju proljevom kod ljudi. Cilj ovoga istraživanja bio je utvrditi prevalenciju različitih gena virulentnosti u izolatima dobivenima iz mesa brojlera u klaonicama u Srbiji. Na prisutnost vrsta roda Campylobacter spp. ukupno je pretraženo 115 uzoraka. Morfološko-biokemijskim pretragama, multipleks PCR tehnikom kao i sekvenciranjem visokoočuvane regije gena dnaJ, koji kodira sintezu proteina DnaJ iz obitelji proteina Hsp40, 35 izolata identificirano je kao C. jejuni. Izolati su pretraženi na prisutnost četiri gena patogenosti: $f l a A, c a d F, c d t B$ i $\operatorname{cgt} B$. Ti su geni odgovorni za ekspresiju adherencije, kolonizacije, sinteze citotoksina $C$. jejuni kao i nastanak Guillain-Barreova sindroma. Izolati su pokazali široku varijaciju u prisutnosti tih gena. Svi su izolati bili pozitivni na gen $f l a A$, pri čemu je u populaciji $C$. jejuni iz ovoga istraživanja utvrđena visoka heterogenost u genetskoj strukturi, koja je djelomice različita od rezultata drugih autora. Kod 94,3\% izolata $C$. jejuni utvrđen je gen $c a d F$, kod $97,1 \% \operatorname{gen} c d t B$, a kod 5,7\% gen $c g t B$. Ovo istraživanje pruža početne podatke o prevalenciji i distribuciji gena $f a A, c a d F, c d t B$ i $c g t B \operatorname{kod} C$. jejuni izoliranih iz mesa brojlera u klaonicama u Srbiji.

Ključne riječi: Campylobacter jejuni, virulentnost, geni, brojleri 
